\title{
KOMPARASI EFEKTIVITAS ANTARA PROBLEM BASED LEARNING (PBL) DAN PROJECT BASED LEARNING (PjBL) TERHADAP KEMAMPUAN BERPIKR KRITIS DITINJAU DARI MOTIVASI BELAJAR MATEMATIKA
}

\author{
Rozi Sianturi, M. Firdaus, dan Utin Desy Susiaty \\ IKIP PGRI Pontianak \\ e-mail: rozisianturi19@gmail.com
}

\begin{abstract}
Abstrak
Tujuan penelitian ini adalah untuk mendeskripsikan perbandingan hasil belajar ranah kemampuan berpikir kritis antara penerapan model pembelajaran PBL dan PjBL pada materi bentuk aljabar ditinjau dari motivasi belajar matematika peserta didik kelas VII. Jenis penelitian ini adalah kuantitatif dengan desain kuasi eksperimen faktorial $2 \times 3$. Populasi dalam penelitian ini adalah seluruh peserta didik kelas VII SMP Negeri 2 Sungai Raya Kepulauan terdiri dari tiga kelas, dengan sampel kelas VII A dan VII B yang dipilih secara random. Pengumpulan data menggunakan instrumen tes dengan bentuk soal uraian. Metode analisis data menggunakan statistik melalui uji anava dua jalan $2 \times 3$ dengan sel tak sama pada data post-test peserta didik. Hasil penelitian menunjukkan bahwa secara signifikan model PBL lebih baik dari pada PjBL terhadap kemampuan berpikir kritis pada materi bentuk aljabar ditinjau dari motivasi belajar matematika peserta didik.
\end{abstract}

Kata Kunci: Problem Based Learning, Project Based Learning, Kemampuan Berpikir Kritis

\begin{abstract}
The purpose of this study is to find out which is better between the Problem Based Learning learning model and the Project-Based Learning learning model on students' critical thinking skills in algebraic form material in terms of the motivation to learn mathematics on the VII grade students of SMP Negeri 2 Sungai Raya Kepulauan. The method used in this study was experimental, with quasi-experimental research forms, and the research design is a $2 \times 3$ factorial design. The population in this study were all grade VII students of SMP Negeri 2 Sungai Raya Kepulauan consisting of three classes, with class VII A and VII B samples selected randomly using the Cluster Random Sampling technique. Based on the analysis of variance of two paths with unequal cells it is concluded that the Problem Based Learning model is better than the Project-Based Learning model towards critical thinking ability on algebraic form material in terms of students' mathematics learning motivation.
\end{abstract}

Keywords: Problem Based Learning, Project-Based Learning, Critical Thinking Ability

\section{PENDAHULUAN}

Pembelajaran yang bermakna merupakan proses belajar yang diharapkan bagi peserta didik, di mana peserta didik dapat terlibat langsung dalam proses pembelajaran serta menemukan langsung pengetahuan tersebut (Primayana, Lasmawan, \& Adnyana, 2019). Untuk terjadinya pembelajaran yang diharapkan sesuai dengan tujuan 
pembelajaran, pendidik harus mampu mengembangkan nalar, kemampuan berpikir dan konsep diri peserta didik seingga menciptakan pembelajaran yang bermakna bagi peserta didik yang berdampak pada hasil belajar. Satu diantara keterampilan yang perlu dimiliki adalah kemampuan berpikir kritis. Kemampuan berpikir kritis sangat dibutuhkan dalam kehidupan manusia, pendidikan memiliki tanggung jawab untuk mencetak peserta didik yang menjadi manusia yang mampu berpikir kritis (Nuraini, 2017). Masalah-masalah yang dihadapi seseorang akan menjadi lebih kompleks seiring perkembangan usia dan lingkungan sosialnya. Untuk dapat survive, seseorang perlu memiliki kemampuan berpikir kritis dan kreatif, karena dengan memiliki kemampuan tersebut ia akan lebih mudah menghadapi masalah dan menyelesaikannya (Happy \& Widjajanti, 2014). Kemampuan berpikir kritis dan kreatif memungkinkan seseorang mempelajari masalah yang dihadapi secara sistematis, menghadapi berbagai tantangan dengan cara yang terorganisir, merumuskan pertanyaan-pertanyaan yang inovatif, dan merancang solusi-solusi yang orisinal (Johnson, 2002; Yuliarti, 2018; Mulyono, 2018).

Kemampuan yang penting dimiliki peserta didik salah satunya adalah kemampuan berpikir kritis (Rahayu \& Hartono, 2016; Mulyono, 2018). Kemampuan tersebut merupakan salah satu kompetensi yang juga harus dikuasai peserta didik dalam pembelajaran matematika. Kemam-puan berpikir kritis menjadi penting bila melihat kondisi zaman sekarang, dimana keadaan sangat cepat berubah serta perkembangan teknologi yang semakin pesat dan sangat kompetitif. Proses pembelajaran di kelas diharapkan mampu mempersiapkan peserta didik untuk memiliki kompe-tensi tersebut agar peserta didik dapat memiliki kemampuan memperoleh, mengelola, dan memanfaatkan informasi untuk hidup lebih baik. Kemampuan berpikir kritis merupakan bagian dari kemampuan berpikir matematis yang perlu dimiliki oleh setiap peserta didik dalam menghadapi berbagai permasalahan (Lestari, 2014). Menumbuhkan kemampuan berpikir kritis sangat penting dalam dunia pendidikan, karena dengan adanya kemampuan berpikir kritis peserta didik akan mampu mengambil keputusan yang tepat dalam suatu permasalahan karena pengambilan keputusan berdasarkan pertimbangan seperti mengenali permasalahan yang dihadapi, menemukan cara untuk dapat menyelesaikan permasalahan tersebut, hingga pada tahap membuat kesimpulan dari keputusan yang diambil.

Hal yang tak kalah penting dalam belajar adalah motivasi belajar. Motivasi belajar dapat timbul karena faktor intrinsik berupa hasrat dan keinginan berhasil serta dorongan kebutuhan belajar dan harapan akan cita-cita (Khamid \& Santosa, 2016). Adanya motivasi belajar dalam diri peserta didik akan menimbulkan dorongan mental untuk melakukan aktivitas belajar untuk mencapai tujuan (Rahayu \& Hartono, 2016). Menurut Emda, (2017) ada tidaknya motivasi belajar sangat mempengaruhi keberhasilan belajar peserta didik. Keberhasilan belajar akan tercapai apabila pada diri adanya kemauan dan dorongan untuk 
belajar. Menurut Suprihatin (2015) motivasi dapat diartikan sebagai kekuatan (energi) seseorang yang dapat menimbulkan tingkat kemauan dalam melaksanakan suatu kegiatan. Hal ini sejalan dengan pendapat yang dikemukakan oleh Lestari (2014) bahwa motivasi belajar yang perlu ditanamakan selama pembelajaran diantaranya dengan menumbuhkan dorongan yang kuat dan kebutuhan belajar, menumbuhkan perhatian dan minat terhadap matematika, melatih ketekunan dan keuletan dalam menghadapi kesulitan, serta menumbuhkan hasrat dan keinginan untuk berhasil. Fauziah, Rosnaningsih, \& Azhar (2017) juga berpendapat bahwa peserta didik yang mempunyai motivasi belajar akan mengerti dengan apa yang menjadi tujuan dalam belajar, disamping itu keadaan peserta didik yang baik dalam belajar akan menyebabkan peserta didik tersebut semangat dalam belajar dan mampu menyelesaikan tugas dengan baik.

Perubahan dalam berbagai komponen pendidikan, seperti model pembelajaran diperlukan untuk mencapai kemampuan yang diharapkan dalam pembelajaran matematika (Simanjuntak, 2020). Hal ini disebabkan karena banyaknya anggapan pada peserta didik, bahwa matematika merupakan sesuatu hal yang sulit, sehingga matematika tidak disukai dalam pembelajaran, yang pada akhirnya prestasi dalam pembelajaran tidak sesuai dengan yang diharapkan. Oleh karena itu, diperlukan suatu model pembelajaran matematika yang harus berorientasi pada peserta didik, yang menekankan pada kemampuan berpikir kritis. Salah satu model pembelajaran yang dapat mengembangkan kemampuan berpikir kritis adalah dengan menerapkan model pembelajaran problem based learning (PBL) dan project based learning (PjBL). Arends \& Kilcher (2010) menyatakan bahwa PBL adalah pembelajaran yang berpusat pada peserta didik dimana intruksi dan kuri-kulumnya di sekitar masalah yang tersusun dalam situasi masalah dunia nyata. Lebih lanjut Arends \& Kilcher (2010) dan Yuliarti (2018) menyatakan bahwa PBL dapat meningkatkan prestasi belajar dan berpikir tingkat tinggi. Aktivitas belajar yang melibatkan pemikiran, pemecahan masalah, dan pemahaman sering memiliki pengaruh lebih bagus pada prestasi peserta didik daripada menggunakan metode pengajaran konvensional (Khamid \& Santosa, 2016 Yuliarti, 2018). Pembelajaran dengan menggunakan PBL melibatkan peserta didik secara aktif dalam proses belajar dan dalam proses mengkontruksi makna dari informasi yang ada sehingga terciptanya suasana yang menyenangkan karena terjadi interaksi antara peserta didik dengan guru dan peserta didik dengan peserta didik, hal ini dapat meningkatkan kemampuan komunikasi matematika peserta didik dan meningkatkan motivasi peserta didik dalam belajar (Khamid \& Santosa, 2016).

PBL adalah suatu model pembelajaran yang dirancang dan dikembangkan untuk mengembangkan kemampuan peserta didik memecahkan masalah (Happy \& Widjajanti, 2014). Menurut Rahayu \& Hartono (2016) PBL efektif diterapkan dalam pembelajaran 
matematika dan merupakan pembelajaran yang berpusat pada peserta didik, karena peserta didik terlibat secara aktif dalam kegiatan penyelesaian masalah. Hal ini sejalan dengan pendapat yang dikemukakan oleh Lestari \& Juanda (2019) yang menyatakan bahwa PBL adalah salah satu model pembelajaran yang menempatkan peserta didik sebagai pusat pembelajaran. PBL mengajarkan peserta didik untuk berpikir kritis dan logis dalam memecahkan suatu masalah berdasarkan pengetahuan yang telah mereka miliki. Begitu juga menurut Muchib (2018) pembelajaran dengan model PBL akan melibatkan peserta didik untuk belajar mnyelesaikan masalah dunia nyata dan sekaligus belajar untuk mengetahui pengetahuan yang diperlukan. PBL memungkinkan peserta didik untuk mengintegrasikan pengetahuan dan keterampilan secara simultan dan mengaplikasikannya dalam konteks yang relevan.

PjBL merupakan salah satu model pembelajaran aktif yang berorientasi pada proyek. Holbrook mendefinisikan PjBL merupakan model untuk kegiatan kelas yang berpusat pada peserta didik, interdisipliner dan terintegrasi dengan isu-isu dan praktek dunia nyata (Capraro, Capraro, \& Morgan, 2013). Interdisipliner adalah keterlibatan secara sadar dan integrasi beberapa disiplin akademis dan metode untuk mempel-ajari masalah atau proyek sentral. Menurut Rahayu \& Hartono (2016) PjBL adalah model pembelajaran yang memberdayakan peserta didik untuk mencapai konten pengetahuan mereka sendiri melalui kegiatan penugasan kompleks dan pada akhirnya peserta didik menghasilkan produk karya peserta didik bernilai dan realistic. Menurut Lestari \& Juanda (2019) model PjBL adalah model pembelajaran yang melibatkan kerja proyek untuk peserta didik. Model pembelajaran ini memberikan kesempatan kepada guru untuk mengelola kelas dengan cara berbeda.

Penelitian sebelumnya mengenai PBL sudah banyak dikaji oleh peneliti antara lain Prayogi \& Asy'ari (2013); Nugraha, Suyitno, \& Susilaningsih (2017); Ismail et al. (2018); Ali, Crawford \& Horn (2019); Dabbagh (2019); Pu et al. (2019) di mana PBL efektif dalam menumbuhkan kemampuan berpikir kritis peserta didik. Demikian pula penelitian tentang implementasi PjBL antara lain Desinta, Bukit, \& Ginting (2017); Rahim, Wilujeng, \& Kuswanto, (2019); Widarti, Rokhim \& Syafruddin (2020; Triana, Anggraito, \& Ridlo (2020) di mana PjBL juga efektif menumbuhkan kemampuan berpikir kritis peserta didik. Penelitian tentang komparasi efektivitas antara kedua model tersebut dalam menumbuhkan kemampuan berpikir kritis peserta didik ditinjau dari motivasi pada pembelajaran matematika dirasa menarik untuk dikaji untuk memberikan informasi baru dalam perkembangan ilmu pengetahuan bidang pendidikan dan pembelajaran.

\section{METODE}


Jenis penelitian ini adalah kuantitatis dengan desain kuasi eksperimen faktorial 2x3. Populasi dalam penelitian ini adalah seluruh peserta didik kelas VII SMP Negeri 2 Sungai Raya Kepulauan. Teknik pengambilan sampel random, yaitu kelas VII A (26 peserta didik) sebagai kelas ekspserimen 1 dan VII B (27 peserta didik) sebagai kelas eksperimen 2 . Pada kelas eksperimen1 diberikan pembelajaran matematika yang mengacu pada PBL, sedangkan kelas eksperimen 2 diberi pembelajaran matematika yang mengacu pada PjBL materi pokok bentuk aljabar. Teknik pengumpulan data menggunakan instrumen tes bentuk uraian dan angket. Angket digunakan untuk memperoleh data motivasi belajar matematika peserta didik dan angket diberikan sebelum diberikan perlakuan model pembelajaran PBL dan model pembelajarn PjBL. Tes yang digunakan untuk memperoleh data kemampuan berpikir kritis. Teknik analisis data menggunakan statistik melalui uji anava dua jalan $2 \times 3$ dengan sel tak sama pada data post-test peserta didik.

\section{HASIL DAN PEMBAHASAN}

Tingkat motivasi belajar peserta didik dalam penelitian ini dikategorikan dalam tiga sub kelompok yaitu sub kelompok motivasi belajar tinggi, kelompok motivasi belajar sedang dan kelompok motivasi belajar rendah. Pembagian kategori motivasi belajar peserta didik ditunjukkan pada Tabel 1.

Tabel 1. Penentuan Kategori Motivasi Belajar Peserta didik

\begin{tabular}{lcc}
\hline \multicolumn{1}{c}{ Kategori } & Ketentuan & Rentang \\
\hline Tinggi & $X>\bar{X}+0,5 s d$ & Nilai $>114$ \\
Sedang & $\bar{X}-0,5 s d \leq X \leq \bar{X}+0,5 s d$ & $105 \leq$ Nilai $\leq 114$ \\
Rendah & $X<\bar{X}-0,5 s d$ & Nilai $<105$ \\
\hline
\end{tabular}

Adapun rata-rata kemampuan berpikir kritis peserta didik ditunjukkan pada Tabel 2.

Tabel 2. Rerata Data Kemampuan Berpikir Kritis Matematis Peserta didik

\begin{tabular}{ccccc}
\hline \multirow{2}{*}{ Model } & \multicolumn{3}{c}{ Motivasi Belajar (bn) } \\
\cline { 2 - 5 } & Tinggi & Sedang & Rendah & $\begin{array}{c}\text { Rerata } \\
\text { Marginal }\end{array}$ \\
\hline PBL & 90,00 & 76,00 & 70,50 & 78,83 \\
PjBL & 79,50 & 72,00 & 61,40 & 70,97 \\
\hline Rerata Marginal & $84,75 \mathrm{~b} 1$ & $74,00 \mathrm{~b} 2$ & $65,95 \mathrm{b3}$ & \\
\hline
\end{tabular}

Uji keseimbangan dilakukan dengan menguji keseimbangan rerata kemampuan berpikir kritis, yakni nilai yang diperoleh dari skor tes pada kelas eksperimen 1 dan kelas eksperimen 2. Sebelum diuji keseimbangan, masing-masing sampel terlebih dahulu diuji apakah berdistribusi normal atau tidak serta diuji apakah berasal dari populasi yang homogen yang ditunjukkan pada Tabel 3.

Tabel 3. Hasil Uji Normalitas Keadaan Awal

\begin{tabular}{lccccc}
\hline Kelompok & $\mathbf{N}$ & Lobs & $\mathbf{L}_{\text {tabel }}$ & Keputusan Uji & Kesimpulan \\
\hline Eksperimen 1 & 26 & 0,149 & 0,173 & Ho diterima & Normal \\
\hline
\end{tabular}




\begin{tabular}{llllll}
\hline Eksperimen 2 & 27 & 0,163 & 0,171 & $\mathrm{H}_{0}$ diterima & Normal \\
\hline
\end{tabular}

Hasil uji normalitas keadaan awal terhadap kemampuan berpikir kritis peserta didik menunjukkan bahwa sampel pada kelas eksperimen 1 dan kelas eksperimen 2 mempunyai nilai $L_{\text {obs }}<L_{\text {tabel }}$. Dengan demikian dapat disimpulkan bahwa sampel pada kelas eksperimen 1 dan kelas eksperimen 2 berasal dari populasi yang berdistribusi normal. Berdasarkan hasil perhitungan uji homogenitas diperoleh nilai statistik uji dari kelompok eksperimen 1 dan kelompok eksperimen 2 adalah $F_{\text {obs }}=0,96$ sedangkan $F_{\text {tabel }}$ untuk tingkat signifikan 0,05 adalah $F_{0,05 ; 25 ; 26}=1,94$. Karena $F_{o b s}=0,96<F_{0,05 ; 25 ; 26}=1,94$ maka $H_{0}$ diterima dan $H_{1}$ ditolak artinya kelas eksperimen 1 dan kelas eksperimen 2 homogen. Hasil uji keseimbangan keadaan awal dengan menggunakan uji t diperoleh $t_{\text {hitung }}=0,192$. Karena $t_{\text {hitung }}=0,192=\{\mathrm{t} \mid \mathrm{t}<-2,008$ atau $\mathrm{t}>2,008\}$ maka $\mathrm{H}_{\mathrm{o}}$ diterima. Hal ini berarti kelas eksperimen 1 dan kelas eksperimen 2 berasal dari dua populasi yang memiliki keadaan awal sama.

Sebelum data kemampuan berpikir kritis peserta didik tersebut diuji dengan anava dua jalan sel tak sama, data tersebut terlebih dahulu diuji prasyarat anava yaitu uji normalitas dan homogenitas. Uji normalitas dilakukan sebanyak 5 kali yaitu uji normalitas kemampuan berpikir kritis peserta didik berdasarkan baris yaitu pada model pembelajaran PBL dan model pembelajaran PjBL. Berdasarkan kolom yaitu pada peserta didik yang memiliki kemampuan berpikir kritis tinggi, sedang dan rendah. Uji homogenitas dilakukan sebanyak 2 kali yaitu antara model pembelajaran PBL dan model pembelajaran PjBL serta antara peserta didik yang memiliki motivasi belajar tinggi, sedang dan rendah. Rangkuman hasil uji normalitas dan homogenitas ditunjukkan pada Tabel 4 dan Tabel 5.

Tabel 4. Hasil Uji Normalitas Data Post-test

\begin{tabular}{|c|c|c|c|c|c|}
\hline Kelompok & Lobs & $\mathbf{N}$ & Daerah Kritis & $\begin{array}{c}\text { Keputusan } \\
\text { Uji }\end{array}$ & Kesimpulan \\
\hline PBL & 0,149 & 26 & $\mathrm{DK}=\{L \mid L>0,17\}$ & $\mathrm{H}_{\mathrm{o}}$ diterima & Normal \\
\hline $\mathrm{PjBL}$ & 0,163 & 27 & $\mathrm{DK}=\{L \mid L>0,17\}$ & $\mathrm{H}_{\mathrm{o}}$ diterima & Normal \\
\hline $\begin{array}{l}\text { Motivasi Belajar } \\
\text { Tinggi }\end{array}$ & 0,127 & 21 & $\mathrm{DK}=\{L \mid L>0,21\}$ & $\mathrm{H}_{\mathrm{o}}$ diterima & Normal \\
\hline $\begin{array}{l}\text { Motivassi Belajar } \\
\text { Sedang }\end{array}$ & 0,17 & 15 & $\mathrm{DK}=\{L \mid L>0,19\}$ & $\mathrm{H}_{\mathrm{o}}$ diterima & Normal \\
\hline $\begin{array}{l}\text { Motivasi Belajar } \\
\text { Rendah }\end{array}$ & 0,191 & 17 & $\mathrm{DK}=\{L \mid L>0,21\}$ & $\mathrm{H}_{\mathrm{o}}$ diterima & Normal \\
\hline
\end{tabular}

Tabel 5. Hasil Uji Homogenitas Data Post-test

\begin{tabular}{|c|c|c|c|c|c|}
\hline Model Pembelajaran & $F_{\text {hitung }}$ & $F_{\text {tabel }}$ & $\mathbf{P}$ & Keputusan Uji & Kesimpulan \\
\hline $\begin{array}{l}\text { PBL dan PjBL } \\
\text { Kemampuan berpikir keritis } \\
\text { Motivasi Tinggi, } \\
\text { Motivasi Sedang } \\
\text { dan Motivasi Rendah }\end{array}$ & $\begin{array}{c}0,602 \\
\mathbf{b}_{\text {hit }} \\
0,602\end{array}$ & $\begin{array}{l}5,99 \\
b_{\text {tabel }} \\
5,99\end{array}$ & $\begin{array}{l}\mathrm{F}_{\mathrm{h}}<\mathrm{F}_{\mathrm{t}} \\
\mathbf{P} \\
\mathrm{b}_{\text {hit }}<\mathrm{b}_{\mathrm{t}}\end{array}$ & $\begin{array}{c}\mathrm{H}_{\circ} \text { diterima } \\
\text { Keputusan Uji } \\
\mathrm{H}_{\circ} \text { diterima }\end{array}$ & $\begin{array}{l}\text { Homogen } \\
\text { Kesimpulan } \\
\text { Homogen }\end{array}$ \\
\hline
\end{tabular}


Uji hipotesis dilakukan dengan uji anava dua jalan. Data hasil perhitungan menggunakan uji analisis variansi dua jalan $(2 \times 3)$ dengan sel tak sama dengan tingkat signifikan $5 \%$ ditunjukkan pada Tabel 6.

Tabel 6. Hasil Perhitungan Dengan Anava Dua Jalan 2 x 3 Dengan Sel Tak Sama

\begin{tabular}{|c|c|c|c|c|c|c|}
\hline Sumber & JK & dk & RK & F obs & $F_{\alpha}$ & $\mathbf{P}$ \\
\hline Model Pembelajaran $(\mathrm{A})$ & 695,829 & 1 & 695,829 & 8,363 & 4,030 & $<0,05$ \\
\hline motivasi belajar (B) & 2667,601 & 2 & 1333,801 & 16,030 & 3,200 & $<0,05$ \\
\hline Interaksi $(\mathrm{AB})$ & 87,728 & 2 & 43,864 & 0,527 & 3,200 & $>0,05$ \\
\hline Galat & 3910,710 & 47 & 83,207 & & & \\
\hline Total & 9406,270 & 53 & & & & \\
\hline
\end{tabular}

bahwa pada efek baris model pembelajaran $\mathrm{H}_{0 \mathrm{~A}}$ ditolak, hal ini berarti terdapat perbedaan kemampuan berpikir keritis antara peserta didik yang menggunakan model pembelajaran PBL dan peserta didik yang menggunakan model pembelajaran PjBL pada materi bentuk aljabar Dengan kata lain ada pengaruh model pembelajaran terhadap kemampuan berpikir kritis peserta didik. Pada efek baris kedua motivasi belajar $\mathrm{H}_{\mathrm{OB}}$ ditolak, hal ini berarti terdapat perbedaan kemampuan berpikir kritis peserta didik yang mempunyai motivasi belajar tinggi, sedang dan rendah pada materi bentuk aljabar. Dengan kata lain terdapat pengaruh kemampuan belajar peserta didik terhadap kemampuan berpikir kritis peserta didik. Dan pada baris interaksi $\mathrm{H}_{\mathrm{OAB}}$ diterima, hal ini berarti tidak terdapat interaksi antara model pembelajaran dan motivasi belajar terhadap kemampuan berpikir kritis pada materi bentuk aljabar. Dengan kata lain, model pembelajaran maupun motivasi belajar peserta didik memiliki pengaruh yang konsisten terhadap kemampuan berpikir kritis atau model pembelajaran yang berbeda memberikan efek yang berbeda pula pada masing-masing tingkat motivasi belajar peserta didik (Septian \& Komala, 2019). maka komparasi ganda perlu dilakukan untuk melihat manakah yang secara signifikan mempunyai rerata yang berbeda (Santoso \& Ariyanto, 2020).

$\mathrm{H}_{0 \mathrm{~A}}$ ditolak dan terdiri dari dua baris model pembelajaran maka efek baris model pembelajaran tidak perlu dilakukan uji lanjut pasca anava. Berbeda dengan efek baris kedua $\mathrm{H}_{0 \mathrm{~B}}$ ditolak dan terdiri dari tiga baris motivasi belajar, maka perlu dilakukan uji lanjut pasca anava dengan metode Scheffe. Setelah dilakukan perhitungan dengan metode Scheffe diperoleh hasil uji komparasi ganda antar kolom yang terangkum pada Tabel 7 .

\begin{tabular}{cccc}
\multicolumn{4}{c}{ Tabel 7. Rangkuman Uji Komparasi Ganda Antar Kolom } \\
\hline $\mathbf{H}_{\mathbf{o}}$ & $\mathbf{F}_{\text {obs }}$ & $\mathbf{2 ~ F}_{0,05 ; 2 ; 66}$ & $\mathbf{p}$ \\
\hline$\mu_{1}=\mu_{2}$ & 12,18 & $2(3,20)=6,40$ & $<0,05$ \\
$\mu_{1}=\mu_{3}$ & 40,07 & $2(3,20)=6,40$ & $<0,05$ \\
\hline
\end{tabular}




\begin{tabular}{llll}
\hline$\mu_{2}=\mu_{3}$ & 11,62 & $2(3,20)=6,40$ & $<0,05$ \\
\hline
\end{tabular}

Uji pasca anava pada Tabel 7 menunjukkan bahwa $\mathrm{H}_{01-2}$ ditolak karena $\mathrm{F}_{1-2}=12,18$ $>6,40$. Hal ini berarti terdapat perbedaan kemampuan berpikir krtitis peserta didik yang memiliki motivasi belajar tinggi dan motivasi belajar sedang pada materi bentuk aljabar (Setyaningsih \& Abadi, 2018). Dilihat dari rerata marginal kemampuan berpikir kritis yang memiliki motivasi belajar tinggi yaitu 84,75 lebih besar dibandingkan rerata marginal kemampuan berpikir kritis peserta didik yang memiliki motivasi belajar sedang yaitu 74,00. Dapat disimpulkan bahwa kemampuan berpikir kritis peserta didik yang memiliki motivasi belajar tinggi lebih baik dibandingkan kemampuan berpikir kritis peserta didik yang memiliki motivasi belajar sedang (Nugraha, Suyitno \& Susilaningsih, 2017). $\mathrm{H}_{01-3}$ ditolak karena $\mathrm{F}_{1-3}$ $=40,07>6,40$. Hal ini berarti terdapat perbedaan kemampuan berpikir keritis peserta didik yang memiliki motivasi belajar tinggi dan motivasi belajar rendah pada materi bentuk aljabar. Dilihat dari rerata marginal kemampuan berpikir keritis yang memiliki motivasi belajar tinggi yaitu 84,75 lebih besar dibandingkan rerata marginal kemampuan berpikir kritis peserta didik yang memiliki motivasi belajar rendah yaitu 65,95. Dapat disimpulkan bahwa kemampuan berpikir kritis peserta didik yang memiliki motivasi belajar tinggi lebih baik dibandingkan kemampuan berpikir kritis peserta didik yang memiliki motivasi belajar rendah. $\mathrm{H}_{0.2-3}$ ditolak karena $\mathrm{F}_{2-3}=11,62>6,40$. Hal ini berarti terdapat perbedaan kemampuan berpikir kritis peserta didik yang memiliki motivasi belajar sedang dan motivasi belajar rendah pada materi bentuk aljabar (Medyasari, Muhtarom \& Sugiyanti, 2017). Dilihat dari rerata marginal kemampuan berpikir kritis yang memiliki motivasi belajar sedang yaitu 74,00 lebih besar dibandingkan rerata marginal kemampuan berpikir keritis peserta didik yang memiliki motivasi belajar rendah yaitu 65,95. Dapat disimpulkan bahwa kemampuan berpikir kritis peserta didik yang memiliki motivasi belajar sedang lebih baik dibandingkan kemampuan berpikir kritis peserta didik yang memiliki motivasi belajar rendah (Rahayu \& Hartono, 2016).

Hipotesis pertama dalam penelitian ini mengatakan bahwa "Peserta didik yang menggunakan model pembelajaran PBL lebih baik dari pada peserta didik yang menggunakan model pebelajaran $\mathrm{PjBL}$ terhadap kemampuan berpikir kritis pada materi bentuk aljabar". Berdasrkan analisis variansi dua jalan sel tak sama, hipotesis pertama teruji kebenarannya secara signifikan dan dapat diterima. Hal ini berarti terdapat perbedaan kemampuan berpikir kritis peserta didik antara model pembelajaran PBL dan model pembelajaran PjBL pada materi bentuk aljabar. Dari rerata marginal dapat disimpulkan bahwa kemampuan berpikir kritis dengan model pembelajaran PBL lebih baik dari pada model pembelajaran PjBL ditinjau dari motivasi belajar peserta didik pada materi bentuk aljabar. Hal ini menunjukkan adanya pengaruh model pembelajaran matematika 
terhadap kemampuan berpikir kritis peserta didik (Siregar, Deniyanti \& \& El Hakim, 2018). Hal ini disebabkan oleh banyak faktor, diantaranya yaitu peserta didik yang diberikan model pembelajaran PBL saling membantu anggota kelompoknya berdiskusi secara sungguh-sungguh (Pratiwi, Hakim \& Siregar, 2020). Selain itu juga, didukung oleh persiapan yang baik dalam model pembelajaran $\mathrm{PBL}$, terutama dalam penyusunan Rencana Pelaksanaan Pembelajaran (RPP).

Hipotesis kedua dalam penelitian ini mengatakan bahwa "Peserta didik yang memiliki motivasi belajar matematika tinggi memiliki kemampuan berpikir kritis yang lebih baik dari pada peserta didik yang memiliki motivasi belajar matematika sedang dan rendah, serta peserta didik yang memiliki motivasi belajar matematika sedang memberikan kemampuan berpikir kritis yang lebih baik dari pada peserta didik yang memiliki motivasi belajar rendah pada materi bentuk aljabar". Berdasarkan analisis variansi dua jalan dengan sel tak sama, hipotesis kedua teruji kebenarannya secara signifikan dan dapat diterima. Hal ini berarti terdapat perbedaan kemampuan berpikir kritis peserta didik yang signifikan ditinjau dari motivasi belajar peserta didik pada materi bentuk aljabar (Zanthy, 2016). Berdasarkan uji pasca anava dengan metode Scheffe dapat disimpulkan bahwa peserta didik yang mempunyai motivasi belajar tinggi memiliki kemampuan berpikir kritis yang lebih baik dibandingkan dengan peserta didik yang memiliki motivasi belajar sedang. Peserta didik yang mempunyai motivasi belajar tinggi memiliki kemampuan berpikir kritis yang lebih baik dibandingkan dengan peserta didik yang memiliki motivasi belajar rendah (Novtiar \& Aripin, 2017). Peserta didik yang mempunyai motivasi belajar sedang memiliki kemampuan berpikir kritis yang lebih baik dibandingkan dengan peserta didik yang memiliki motivasi belajar rendah (Mulyati, Suryani \& Setiawan, 2019). Dari uraian tersebut dapat disimpulkan bahwa dalam penelitian ini peserta didik yang memiliki motivasi belajar tinggi memiliki kemampuan berpikir kritis yang lebih baik dari pada peserta didik yang memiliki motivasi belajar sedang dan rendah, serta peserta didik yang memiliki motivasi belajar sedang memiliki kemampuan berpikir kritis yang lebih baik dari pada peserta didik yang memiliki motivasi belajar rendah pada materi bentuk aljabar (Novtiar \& Aripin, 2017).

Hal ini disebabkan semakin tinggi motivasi belajar peserta didik, maka semakin tinggi pula kemampuan berpikir kritisnya, karena peserta didik yang motivasi belajar tinggi itu biasanya lebih semangat dan aktif dalam pembelajaran, biasanya sering bertanya jika ada sesuatu yang belum dimengerti, selalu mencari informasi yang belum diketahui dalam pembelajaran, sehingga memengaruhi kemampuan berpikir kritisnya dalam menyelesaikan permasalahan matematika (Irniansyah, 2019). Berbeda dengan motivasi belajar sedang, peserta didik cenderung akan melakukan sesuatu separuhnya dan tidak total bersungguhsungguh dalam proses pembelajaran, sehingga yang dilakukan peserta didik dalam proses pembelajaran tidak seefektif peserta didik yang tergolong motivasi belajar tinggi. 
Sedangkan pada peserta didik yang tergolong motivasi belajar rendah cenderung kurang bersemangat dan kurang aktif dalam proses pembelajaran. Dengan demikian, motivasi belajar peserta didik yang berbeda akan memiliki pengaruh yang berbeda pula terhadap kemampuan berpikir kritisnya (Anita, 2015).

Hasil perhitungan analisis variansi dua jalan dengan sel tak sama diperoleh $\mathrm{H}_{O A B}$ diterima yang berarti tidak terdapat interaksi antara model pembelajaran dan motivasi belajar peserta didik pada materi bentuk aljabar. Karena tidak terdapat interaksi antara model pembelajaran dan motivasi belajar, maka perbandingan antara model pembelajaran PBL dan PjBL untuk setiap motivasi belajar peserta didik mengikuti perbandingan marginalnya. Hasil penelitian ini sejalan dengan beberapa hasil penelitian terdahulu. Penelitian yang dilakukan oleh (Khamid \& Santosa, 2016) yang menyimpulkan bahwa pendekatan PBL lebih efektif daripada pendekatan CTL ditinjau dari motivasi belajar peserta didik. Sejalan dengan penelitian yang dilakukan oleh Rahayu \& Hartono (2016) menyimpulkan bahwa model pembelajaran PBL setting Gl dan PjBL setting Gl efektif ditinjau dari prestasi belajar, kemampuan berpikir kritis, dan motivasi belajar matematika. Penelitian yang dilakukan oleh Lestari \& Juanda (2019) menyimpulkan bahwa pembelajaran PBL lebih baik dari pembelajaran PjBL pada materi perangkat keras jaringan internet terhadap hasil belajar peserta didik. Begitu juga dengan hasil penelitian yang dilakukan oleh Ismail (2015) menyimpulkan bahwa PBL lebih efektif dibandingkan PjBL pada materi pelajaran geometri sisi datar dalam hal pencapaian pembelajaran matematika.

\section{SIMPULAN}

Simpulan dari penelitian ini adalah bahwa secara signifikan model PBL memberikan kemampuan berpikir kritis lebih baik dibandingkan model pembelajaran PjBL. Motivasi belajar matematika yang tinggi memberikan kemampuan berpikir keritis lebih baik secara signifikan dibandingkan dengan motivasi belajar matematika sedang dan rendah. Pada masing-masing model pembelajaran, kemampuan berpikir kritis peserta didik dengan motivasi belajar matematika tinggi lebih baik secara signifikan dari pada motivasi belajar matematika sedang dan rendah. Pada masing-masing motivasi belajar matematika, kemampuan berpikir kritis peserta didik dengan model pembelajaran PBL memberikan kemampuan berpikir kritis lebih baik secara signifikan dari pada pembelajaran PjBL. Berdasarkan hal tersebut, model PBL lebih direkomendasikan dalam pembelajaran matematika materi aljabar untuk menumbuhkan motivasi belajar dan kemampuan berpikir kritis peserta didik.

\section{DAFTAR PUSTAKA}


Ali, N., Crawford, R., \& Horn, M. 2019. Critical thinking in PBL: Development of a Bespoke Tool for Critical Thinking. In HEAD'19. 5th International Conference on Higher Education Advances (pp. 513-520). Editorial Universitat Politècnica de València.

Anita, I. W. A. W. 2015. Pengaruh Motivasi Belajar Ditinjau dari Jenis Kelamin terhadap Kemampuan Berpikir Kritis Matematis. Jurnal IImiah P2M STKIP Siliwangi, 2(2), 246251.

Arends, R. ., \& Kilcher, A. 2010. Teaching for Student Learning "Becoming an Accumplhised Teacher.” New York: Routladge Taylor \& Francis Group.

Budiyono. 2009. Statistik untuk Penelitian. Surakarta: UNS Press.

Capraro, R. M., Capraro, M. M., \& Morgan, J. R. 2013. STEM Project-Based Learning. Rotterdam, The Netherlands: Sense Publishers.

Dabbagh, N. 2019. Effects of PBL on Critical Thinking Skills. The Wiley Handbook of Problem-Based Learning, 135-156.

Desinta, F., Bukit, N., \& Ginting, E. M. 2017. The Effect ofProject Based Learning (PjBL) andSelf Regulated Learningtoward Students' Critical Thinking Skill in Senior High School. IOSR Journal of Research \& Method in Education (IOSR-JRME), 7(4), 59-63.

Emda, A. 2017. Kedudukan Motivasi Belajar Siswa Dalam Pembelajaran. Lantanida Journal, 5(2), 172. https://doi.org/10.22373/lj.v5i2.2838

Fauziah, A., Rosnaningsih, A., \& Azhar, S. 2017. Hubungan antara Motivasi Belajar dengan Minat Belajar Siswa Kelas IV SDN Poris Gaga 05 Kota Tangerang. JURNAL JPSD, 4(1), 47-53.

Happy, N., \& Widjajanti, D. B. 2014. Keefektifan PBL Ditinjau dari Kemampuan Berpikir Kritis dan Kreatif Matematis, serta Self-Esteem Siswa SMP. Jurnal Riset Pendidikan Matematika, 1(1), 48. https://doi.org/10.21831/jrpm.v1i1.2663

Irniansyah, L. 2019. Pengaruh Metode Inkuiri dan Motivasi Belajar terhadap Kemampuan Berpikir Kritis Siswa (Survey Pada Siswa Kelas X IPS Mata Pelajaran Ekonomi SMA YPI Bandung Tahun Ajaran 2018/2019) (Doctoral dissertation, FKIP UNPAS).

Ismail, R. 2015. ME - 7 The Comparison of Effectiveness of Project Based Learning and Problem Based Learning on The Space Model of Flat Side in Terms of Achievement of Learning Objectives. (May), 17-19.

Ismail, N. S., Harun, J., Zakaria, M. A. Z. M., \& Salleh, S. M. 2018. The Effect of Mobile Problem-Based Learning Application DicScience PBL on Students' Critical Thinking. Thinking Skills and Creativity, 28, 177-195.

Johnson, E. B. 2002. Contextual Teaching and Learning. Thausand Oaks, California: Corwin Press, Inc. A Sage Publication Company.

Khamid, A., \& Santosa, R. H. 2016. Keefektifan Pendekatan PBL dan CTL Ditinjau dari Komunikasi Matematis dan motivasi Belajar Siswa SMP. PYTHAGORAS: Jurnal Pendidikan Matematika, 11(2), 111. https://doi.org/10.21831/pg.v11i2.10660

Lestari, I., \& Juanda, R. 2019. Komparasi Model Pembelajaran Problem Based Learning dan Project Based Learning Terhadap Hasil Belajar Siswa pada Materi Perangkat 
Keras Jaringan Internet Kelas IX SMP Negeri 5 Sungai Kakap Kabupaten Kubu Raya. Efektor, 6(2), 127-135.

Lestari, K. E. 2014. Implementasi Brain Based Learning untuk Meningkatkan Kemampuan Koneksi dan Kemampuan Berpikir Kritis serta Motivasi Belajar Siswa SMP. JURNAL PENDIDIKAN UNSIKA, 2(1), 36-46.

Medyasari, L. T., Muhtarom, M., \& Sugiyanti, S. 2017. Efektivitas Model Pembelajaran Group Investigation Berbantuan Kartu Soal Terhadap Prestasi Belajar Ditinjau Dari Motivasi Belajar Pada Materi Turunan Fungsi Aljabar. AKSIOMA: Jurnal Matematika dan Pendidikan Matematika, 8(1), 65-75.

Muchib, M. 2018. Penerapan model PBL dengan Video untuk meningkatkan Minat dan prestasi Belajar Bahasa Indonesia. Wiyata Dharma: Jurnal Penelitian Dan Evaluasi Pendidikan, 6(1), 25. https://doi.org/10.30738/wd.v6i1.3356

Mulyati, S., Suryani, Y., \& Setiawan, I. 2019. Pengaruh Penerapan Model Pembelajaran Open Ended terhadap Kemampuan Berpikir Kritis Siswa Dengan Variabel Moderator Motivasi Belajar. Equilibrium: Jurnal Penelitian Pendidikan dan Ekonomi, 16(02), 123132.

Mulyono, Y. 2018. Critical Thinking Skills of Physics Education Students through CTLBased Fundamental Biology. In Science, Engineering, Education, and Development Studies (SEEDS): Conference Series (Vol. 2, No. 1).

Mulyono, Y. 2018. Improving Creativity of the Future Physics Teachers through General Biology Learning Based on CTL with Experimental Method. Indonesian Journal of Science and Education, 2(1), 1-7.

Novtiar, C., \& Aripin, U. 2017. Meningkatkan Kemampuan Berpikir Kritis Matematis dan Kepercayaan Diri Siswa SMP Melalui Pendekatan Open Ended. Prisma, 6(2), 119131.

Nugraha, A. J., Suyitno, H., \& Susilaningsih, E. 2017. Analisis Kemampuan Berpikir Kritis Ditinjau dari Keterampilan Proses Sains dan Motivasi Belajar melalui Model PBL. Journal of Primary Education, 6(1), 35-43.

Nuraini, N. 2017. Profil Keterampilan Berpikir Kritis Mahasiswa Calon Guru Biologi Sebagai Upaya Mempersiapkan Generasi Abad 21. DIDAKTIKA BIOLOGI: Jurnal Penelitian Pendidikan Biologi, 1(2), 89-96.

Pratiwi, L. L., Hakim, L., \& Siregar, N. 2020. Penerapan Model Pembelajaran Problem Based Learning untuk Meningkatkan Keaktifan Belajar Siswa Kelas IV Di MIN 04 Muaro Jambi (Doctoral dissertation, UIN Sulthan Thaha Saifuddin Jambi).

Prayogi, S., \& Asy'ari, M. 2013. Implementasi Model PBL (Problem Based Learning) untuk Meningkatkan Hasil Belajar dan Kemampuan Berpikir Kritis Siswa. Prisma Sains: Jurnal Pengkajian IImu dan Pembelajaran Matematika dan IPA IKIP Mataram, 1(1), 80-88.

Primayana, K. H., Lasmawan, I. W., \& Adnyana, P. B. 2019. Pengaruh Model Pembelajaran Kontekstual Berbasis Lingkungan Terhadap Hasil Belajar IPA Ditinjau dari Minat Outdoor pada Siswa Kelas IV. Jurnal Pendidikan dan Pembelajaran IPA Indonesia, 9(2), 72-79. 
Pu, D., Ni, J., Song, D., Zhang, W., Wang, Y., Wu, L., ... \& Wang, Y. 2019. Influence of Critical Thinking Disposition on the Learning Efficiency of Problem-Based Learning in Undergraduate Medical Students. BMC medical education, 19(1), 1.

Rahayu, E., \& Hartono, H. 2016. Keefektifan Model PBL dan PjBL Ditinjau dari Prestasi, Kemampuan Berpikir Kritis, dan Motivasi Belajar Matematika Siswa SMP. PYTHAGORAS: Jurnal Pendidikan Matematika, 11(1), 1. https://doi.org/10.21831/pg.v11i1.9629.

Rahim, A. C., Wilujeng, I., \& Kuswanto, H. 2019. The Effect of PjBL Model Based on Skill Approach Process to Physics Critical Thinking Ability of High School Student. In Journal of Physics: Conference Series (Vol. 1233, No. 1, p. 012040). IOP Publishing.

Santoso, M. F., \& Ariyanto, M. P. 2020. Perbedaan Hasil Belajar Matematika Siswa Kelas VIII MTs Negeri Surakarta 1 Ditinjau dari Gaya Belajar Siswa (Doctoral dissertation, Universitas Muhammadiyah Surakarta).

Septian, A., \& Komala, E. 2019. Kemampuan Koneksi Matematik dan Motivasi Belajar Siswa dengan Mengunakan Model Problem-Based Learning (PBL) Berbantuan Geogebra di SMP. Prisma, 8(1), 1-13.

Setyaningsih, T. D., \& Abadi, A. M. 2018. Keefektifan PBL Seting Kolaboratif Ditinjau dari Prestasi Belajar Aljabar, Kemampuan Berpikir Kritis, dan Kecemasan Siswa. Jurnal Riset Pendidikan Matematika, 5(2), 190-200.

Simanjuntak, T. D. L. 2020. Analisis Kemampuan Berpikir Kritis Serta Disposisi Matematis Siswa Melalui Penerapan Model Pembelajaran Coopertive Type Jigsaw Pada Siswa Kelas X Sma Global Prima (Doctoral dissertation, UNIMED).

Siregar, N. A. R., Deniyanti, P., \& El Hakim, L. 2018. Pengaruh Model Pembelajaran Core Terhadap Kemampuan Berpikir Kritis dan Disposisi Matematis Ditinjau dari Kemampuan Awal Matematika Siswa SMA Negeri di Jakarta Timur. JPPM (Jurnal Penelitian dan Pembelajaran Matematika), 11(1).

Suprihatin, S. 2015. Upaya Guru dalam Meningkatkan Motivasi Belajar Siswa. PROMOSI (Jurnal Pendidikan Ekonomi), 3(1), 73-82. https://doi.org/10.24127/ja.v3i1.144

Triana, D., Anggraito, Y. U., \& Ridlo, S. 2020. Effectiveness of Environmental Change Learning Tools Based on STEM-PjBL towards 4C Skills of Students. Journal of Innovative Science Education, 9(2), 181-187.

Widarti, H. R., Rokhim, D. A., \& Syafruddin, A. B. 2020. The Development of Electrolysis Cell Teaching Material Based on STEM-PjBL Approach Assisted by Learning Video: A Need Analysis. Jurnal Pendidikan IPA Indonesia, 9(3), 309-318.

Yuliarti, Y. 2018. Kreativitas Mahasiswa dalam Mengembangkan Paragraf melalui Pembelajaran Bahasa Indonesia dengan Pendekatan PBL. Indonesian Journal of Learning Education and Counseling, 1(1), 42-46.

Zanthy, L. S. 2016. Pengaruh Motivasi Belajar Ditinjau dari Latar Belakang Pilihan Jurusan terhadap Kemampuan Berpikir Kritis Mahasiswa di STKIP Siliwangi Bandung. TEOREMA: Teori Dan Riset Matematika, 1(1), 47-54. 